\title{
Mycoremediation of PCBs by Pleurotus ostreatus: Possibilities and Prospects
}

\author{
Se Chul Chun ${ }^{1} \mathbb{D}$, Manikandan Muthu ${ }^{1}$, Nazim Hasan ${ }^{2}$, Shadma Tasneem ${ }^{2}$ and Judy Gopal ${ }^{1, * \mathbb{D}}$ \\ 1 Department of Environmental Health Sciences, Konkuk University, Seoul 143-701, Korea; \\ scchun@konkuk.ac.kr (S.C.C.); bhagatmani@gmail.com (M.M.) \\ 2 Department of Chemistry, Faculty of Science, Jazan University, Jazan, P.O. Box 114, Saudi Arabia; \\ nazim7862000@gmail.com (N.H.); sthaque@jazanu.edu.sa (S.T.) \\ * Correspondence: jejudy777@gmail.com; Tel.: +82-2450-0574; Fax: +82-2450-3310
}

Received: 22 August 2019; Accepted: 21 September 2019; Published: 8 October 2019

\begin{abstract}
With the rising awareness on environmental issues and the increasing risks through industrial development, clean up remediation measures have become the need of the hour. Bioremediation has become increasingly popular owing to its environmentally friendly approaches and cost effectiveness. Polychlorinated biphenyls (PCBs) are an alarming threat to human welfare as well as the environment. They top the list of hazardous xenobiotics. The multiple effects these compounds render to the niche is not unassessed. Bioremediation does appear promising, with myco remediation having a clear edge over bacterial remediation. In the following review, the inputs of white-rot fungi in PCB remediation are examined and the lacunae in the practical application of this versatile technology highlighted. The unique abilities of Pleurotus ostreatus and its deliverables with respect to removal of PCBs are presented. The need for improvising P. ostreatus-mediated remediation is emphasized.
\end{abstract}

Keywords: mycoremediation; PCBs; Pleurotus; xenobiotics; fungus

\section{Introduction}

The synthetic compounds obtained through chlorination of biphenyls are called polychlorinated biphenyls (PCBs), which are composed of a biphenyl molecule (two benzene rings linked by a C-C bond) that carries one to ten chlorine atoms. PCBs as mixtures are commercialized with trade names Aroclor, Clophen, Delor, etc. These commercialized PCBs consist of a mixture of congeners distinguished based on the number and position of chlorines on the biphenyl nucleus. PCBs find place in numerous industrial applications, such as heat transfer fluids, dielectric fluids, hydraulic fluids, flame-retardants, solvent extenders, and organic diluents.

The use of PCBs is expanding and widespread these days, and these compounds are contributing more than enough damage to the environment with their percolation into soil and sedimenting, as there are inadequacies in their waste disposal [1,2]. According to a recent finding, traces of PCBs were still detected in places where production was carried on decades before, in spite of their restricted application then-and this does not even take into account the situation now with large-scale production, of late, to meet the large-scale applications. Currently, PCBs are considered as one of the most hazardous contaminants in the world, and hence, they are the topmost public health concern [3]. The teratogenic, carcinogenic, and endocrine-disrupting aspects of these xenobiotics have been well documented [4-9]. The most alarming adverse property of PCBs is their tendency toward bioaccumulation in lipid tissues and organic components of the soil and adipose tissue of animals and humans [10]. 
This review briefly dwells on the available bioremediation-based technologies for decontamination of PCBs with special focus on white-rot fungi and more so with Pleurotus ostreatus. The milestones achieved so far with P. ostreatus and their future prospects are presented.

\section{Bioremediation of PCBs}

With all the raising environmental considerations, the clean-up of PCB-contaminated sites has drawn everybody's attention and has become a top priority. Among the many remediation approaches that are available, the use of biological systems represents an effective, cost-competitive, and environmentally friendly alternative to the more commonly used thermal and physicochemical technologies [11]. The most prevalent existing practice in the removal of PCBs from contaminated materials is by incineration at high temperatures. In this procedure, the limitations to be faced are that it is expensive, brings additional risk of producing toxic chlorinated dioxins by combustion under lower temperatures, and has inherent volume limits. Therefore, studies on PCB biodegradation by microbes for the decontamination of water and soil systems have been gaining popularity. Decontamination of soil systems with respect to bioremediation has been well established compared to decontamination in water systems. With key advantages such as cost effectiveness and environmental friendliness gaining emphasis (as with any bioremediation system), bioremediation has received much acceptance.

Bacteria plays a key role in PCB biodegradation processes, it has been found. In addition, aerobes and anaerobes have also been reported to participate in their own way in the process. Highly chlorinated biphenyls can be used by anaerobes as electron acceptors, and it is possible to convert them into less chlorinated congeners. Aerobic microorganisms, on the other hand, can deal and co-metabolize lower chlorinated biphenyls [12-14]. Thus, both anaerobic-aerobic treatments are required to completely mineralize these xenobiotics. Bacterial PCB biodegradation in natural compartments is also well documented $[15,16]$. PCB congeners with four or more chlorine atoms undergo bacterial anaerobic reductive dechlorination, while the lower chlorinated PCB congeners are subjected to co-metabolic aerobic oxidation mediated by dioxygenases, encoded by the bphA gene family [17].

The process of PCB biodegradation mediated by fungi is also well established. Fungi's capacity to transform several PCB congeners in liquid medium have been described [18-36]. A few studies established the successful fungal transformation capacity in soils [18-24]. Unlike bacteria, ligninolytic cultures of Phanerochaete chrysosporium, a white-rot fungus, can mineralize tetrachloro- and hexachloro-substituted PCB congeners as well as Aroclor 1254 [37,38]. Other studies have proven that P. chrysosporium degrades higher levels (10 ppm) of Aroclor 1242, 1254, and 1260 [39].

Fungi, mostly wood-degrading basidiomycetes, are well established for PCB removal [40]. The elaborate fungal hyphae can easily penetrate into the polluted matrix. Additionally, the extracellular oxidative enzymes can scavenge even scarcely bioavailable contaminants by nonspecific radical-based reactions. Thus, comparing bacteria and fungi, the latter are said to be more acceptable and recognized for their inputs towards PCB removal. White-rot fungi (WRF) are the most active degraders of lignin to $\mathrm{CO}_{2}$ in plants [41-44]. Earlier reports by Bumpus et al. [45] and Eaton [46] indicated that the white-rot fungus $P$. chrysosporium degrades dioxins, polychlorinated biphenyls (PCBs), and other chloroorganics. P. chrysosporium is the most extensively studied of the ligninolytic white-rot fungi that mineralizes xenobiotics [47-50]. Several white-rot fungi were tested for their ability to decompose PCBs [51]. Numerous studies have confirmed that white-rot fungi including P. chrysosporium [52], Trametes versicolor [53], Lentinus edodes [22], Phlebia brevispora [54], Irpex lacteus, Bjerkanderaadusta, Pycnoporus cinnabarinus, Phanerochaete magnoliae [55], and particularly Pleurotus ostreatus [28,55] could successfully orchestrate PCB removal [1]. However, only a relatively small number of white-rot species have been tested on real PCB-contaminated soil [29], although P. ostreatus is, thus far, likely the most efficient known PCB-degrading organism [28]. 


\section{P. ostreatus Based Degradation of PCBs: Milestones Achieved}

The oyster mushroom, P. ostreatus, is a common mushroom, first cultivated as a subsistence measure during World War I. Now grown commercially around the world for food, oyster mushrooms have been found more useful in industries, i.e., for mycoremediation purposes. As established by earlier researchers, $P$. ostreatus is the one that is now accepted to be highly promising for removal of PCBs. The state-of-the-art contribution of P. ostreatus in this area of bioremediation of PCBs is briefly presented below.

Zeddel et al., 1993 [26], demonstrated that P. ostreatus selectively removed PCBs from soil homogenized with wood chips. P. ostreatus was successfully applied at contaminant concentrations ranging from 100 to $650 \mathrm{ppm}$ for single isomers and $2500 \mathrm{ppm}$ for all PCBs. However, P. chrysosporium could not degrade any PCB except mono- and dichlorbiphenyl in a solid-state system under normal oxygen levels. However, with this limitation, P. chrysosporium was still reported to be the most versatile of the WRF to degrade Aroclor 1242, 1254, and 1260 [1]. However, with respect to bioremediation of PCB in soil, other WRFs like Bjerkandera adusta, P. ostreatus, and T. versicolor exhibited higher biodegradation than P. chrysosporium. Kubátová et al. [28], studied six strains of white-rot fungi for their biodegradation ability of low chlorinated polychlorinated biphenyl (PCB) in real soil system. Phanerochaete chrysosporium and Trametes versicolor did not show any ability to degrade PCBs in soil. By contrast, four strains of $P$. ostreatus were able to remove about $40 \%$ of Delor 103 in two months. All P. ostreatus strains decomposed PCBs selectively with the preference for congeners with chlorine atoms at ortho $>$ meta $>$ para positions. This study confirms $P$. ostreatus' unequivocal ability to perform in real world soil environments more efficiently compared to the others (who were all reported to be well accomplished laboratory scale achievers).

P. ostreatus produces ligninolytic enzymes which are able to interact with a plethora of waste substrates [33-35], including PCBs [36]. This mushroom's industrial cultivation faces a problem: the huge turnover of spent mushroom substrate (SMS), a lignocellulosic matrix, that has to be disposed of [56]. With this as the choke, the exploration of new applications for re-utilization of SMS became desirable. SMS is reported to contain high levels of residual extracellular oxidoreductases produced by the still metabolically active mycelium. It is the niche for active microbial community composed of fungi and bacteria $[57,58]$. Thus, application of SMS in bioremediation processes has been probed, and the ability of the SMS and its inherent microbiota to transform different contaminants has been reported [59-61]. SMS from P. ostreatus was previously validated as a low-cost organic substrate for remediation of polycyclic aromatic hydrocarbon (PAH)-contaminated soil [62,63]. Moreover, lignosulfonate, an inducer of lignolytic activity, was found to possess no effect on the degradation of PCBs with P. ostreatus or Trametes versicolor. An oxygen concentration of $10 \%$ inside the substrate combined with $10 \% \mathrm{CO}_{2}$ also had no influence on the degradation potential of P. ostreatus. Monika et al. [64] carried out an experiment using a mixture of substrate/SMS and sandy soil with PCBs. The results indicated that degradation was dependent on substrate/SMS addition, the concentration of PCBs, and time of incubation. The degree of degradation of a single PCB after 12 weeks of incubation for Agaricus bisporus ranged from $31.32 \pm 1.52$ to $83.91 \pm 1.07 \%$, while for P. ostreatus, it was between $37.88 \pm 2.54$ and $78.29 \pm 1.41 \%$ [65].

\section{Mechanism of Bioremediation by P. ostreatus}

It is known that extracts from WRF or their laccases catalyze the degradation of hydroxylated PCBs. However, as it stands, little is known about the in vivo mechanisms of PCB degradation $[24,66]$. Laccases degrade isolated PCBs congeners [67] or PCBs in commercial mixes such as Delor 103, Delor 106, and Arochlors 1242, 1254, and 1260 [1,58], but the limitation was that higher chlorination levels reduced the degradation efficiency. Most of these studies have been applied on low PCB concentrations only (1-2000 ppm). Canales et al., 2012 [36], determined the correlation of P. ostreatus laccase activity through their conformation on its transcript expression with the removal of high concentrations 
(7100 ppm) of PCBs from Arochlor 1242 in liquid culture. This ability of P. ostreatus was significantly marked in that it was not influenced by the chlorination levels.

P. ostreatus, in the presence of a fungal growth substrate (e.g., lignocellulosic matrices), could transform PCBs in spiked and actually contaminated soils [26,27]. Myco-augmentation of contaminated matrices by this fungus is operational via substrate-unspecific extracellular and intracellular oxido reductases, laccases, and Mn-dependent and -independent peroxidases [28-30], enabling them to transform PCBs [24]. Additionally, P. ostreatus produces ligninolytic enzymes, which is an added asset, whereby it orchestrates the transformation of a plethora of waste substrates [31-33] including PCBs [34-36]. The exact mechanism whereby P. ostreatus degrades PCB is not worked out, but with the rich reservoirs of enzymes such as Lignin Peroxidases, managanese peroxidases, and laccases, there is no doubt that these enzymes will play a synergistic role, if not for individual contributions (Figure 1).

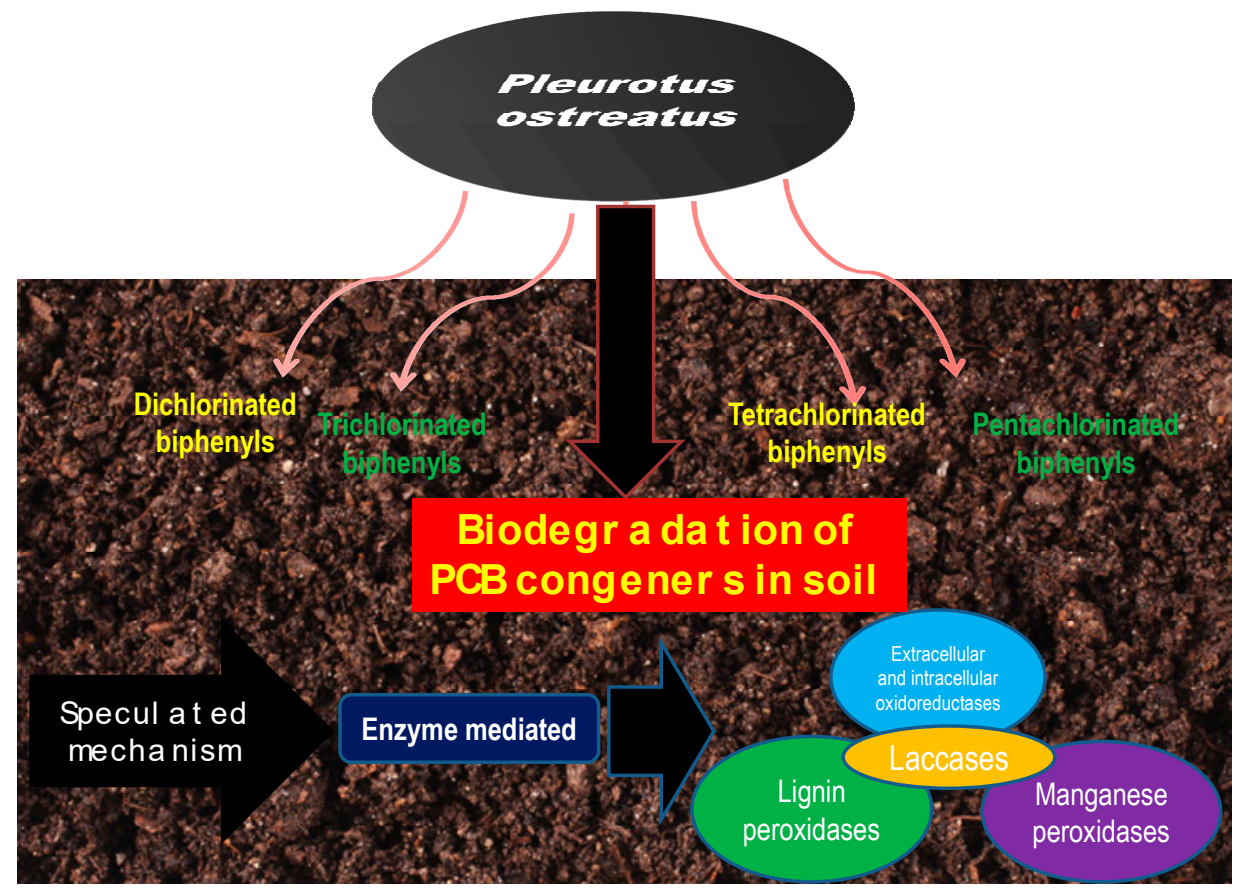

Figure 1. Schematic representation of the overview of bioremediation of polychlorinated biphenyls (PCBs) by P. ostreatus.

\section{P. ostreatus-Based Degradation of PCBs: Future Prospects}

As surmised in an earlier section, P. ostreatus does have an unequivocal edge over other WRFs when it comes to bioremediation of PCBs. The future prospects of this fungus towards the removal of PCBs are thus highly promising. In recent times, bioremediation processes more and more often employ immobilization methods. Immobilization is defined as limiting the mobility of the microbial cells or their enzymes with a simultaneous preservation of their viability and catalytic functions [68-72]. There are five main techniques of immobilization: adsorption, binding on a surface (electrostatic or covalent), flocculation (natural or artificial), entrapment, and encapsulation. This review identifies that no incorporation of such upgraded techniques available for preparing fungal masses for bioremediation protocols has been implanted for P. ostreatus-based degradation of PCBs. Since the fact that $P$. ostreatus can deliver much when it comes to PCBs remains unquestioned, it is now necessary that the biotechnological innovations are put to use for preparing this fungal biomass in the most efficient form. Most of the studies demonstrated on removal of PCBs using P. ostreatus merely use the hyphae as it is. More research on how the fungi can best be prepared for maximizing the PCB recovery is the need of the hour. 
Immobilization of hyphae in columns as micro or nanobeads will enhance the surface-active area; further, incorporation of hyphae in polymer matrices as well as nanomaterials could significantly enhance the bioremediation aspects of P. ostreatus with respect to PCBs. Anna et al. recently presented an exhaustive list of options of natural carriers for bioremediation ranging from naturally occurring materials to nanopolymers [73]. With such options and advancements available, we strongly suggest some amount of improvisation into the routines to harness the best that this fungus has to offer toward bioremediation of PCBs. The SMS of P. ostreatus as explained in the previous section, which showed extensive PAH removal activity, is an area worth developing on with respect to PCBs. The SMS of P. ostreatus has been limited to a single study [64] for PCB degradation. This study showed that the differences between PCB degradation by substrate and SMS of P. ostreatus were very weak; hence, they suggested that it is possible to use SMS for the decontamination of PCB polluted soil. The Council Directive 1999/31/EC declared that each European Union country should reduce the amount of organic refuse by $50 \%$ by 2050 [74]. Poland, Korea, and China are the biggest producers of P. ostreatus, annually generating over a thousand tons of spent mushroom substrate. The proper channelizing of the SMS of this mushroom towards PCB remediation could solve the problem of disposal of this mushroom's refuse. Additionally, the use of the SMS allows for standardization of the exact dose requirement with respect to specific PCB concentrations or environmental conditions. Furthermore, SMS not only decontaminates the soil but is also a high value fertilizer. Further, every technology projection is weighed for its versatility and usefulness based on its cost effectiveness, with the SMS of this fungi showing degradation ability on par with the substrate/mycelium. In this direction, we are certainly talking of a major advantage in terms of cost-effectiveness while using the spent mushroom waste and not the mushroom itself. There is a high prospect that this venture could be highly prospective and cost-effective.

\section{Conclusions}

Only scattered reports and research are available in the direction of PCB degradation using $P$. ostreatus. This review hopes to enthuse researchers working on these lines to extend their biotechnological novelty aspects to this application, in order to harness the best that P. ostreatus could offer towards bioremediation of PCBs and other organopollutants. The utilization of SMS of this fungus, which would prove to be highly cost-effective, ideally needs to be entertained, and more real-time applications realized are emphasized.

Author Contributions: Conceptualization, S.C.C. and J.G.; writing-original draft preparation and review and editing, J.G. and M.M.; writing—review and editing, N.H. and S.T.

Funding: This research received no external funding.

Conflicts of Interest: The authors declare no conflicts of interest.

\section{References}

1. Yadav, J.S.; Wallace, R.E.; Reddy, C.A. Mineralization of mono- and dichlorobenzenes and simultaneous degradation of chloro- and methyl-substituted benzenes by the white rot fungus Phanerochaete chrysosporium. Appl. Environ. Microbiol. 1995, 61, 677-680. [PubMed]

2. Pointing, S.B. Feasibility of bioremediation by white-rot fungi. Appl. Environ. Microbiol. 2011, 57, 20-23.

3. Ross, G. The public health implications of polychlorinated biphenyls (PCBs) in the environment. Ecotoxicol. Environ. Saf. 2004, 59, 275-291. [CrossRef] [PubMed]

4. Crinnion, W.J. Polychlorinated biphenyls: Persistent pollutants with immunological, neurological and endocrinological consequences. Alternat. Med. Rev. 2011, 16, 5-13.

5. El Majidi, N.; Bouchard, M.; Carrier, G. Systematic analysis of the relationship between standardized prenatal exposure to polychlorinated biphenyls and mental and motor development during follow-up of nine children cohorts. Regul. Toxicol. Pharm. 2013, 66, 130-146. [CrossRef] [PubMed] 
6. Kramer, S.; Moller Hikel, S.; Adams, K.; Hinds, D.; Moon, K. Current status of the epidemiologic evidence linking polychlorinated biphenyls and non-Hodgkin lymphoma and the role of immune dysregulation. Environ. Health Perspect. 2012, 120, 1067-1075. [CrossRef] [PubMed]

7. Muscat, J.E.; Britton, J.A.; Djordjevic, M.V.; Citron, M.L.; Kemeny, M.; Busch-Devereaux, E.; Pittman, B.; Stellman, S.D. Adipose concentrations of organochlorine compounds and breast cancer recurrence in Long Island, New York. Cancer Epidemiol. 2003, 12, 1474-1478.

8. Helmfrid, I.; Berglund, M.; Löfman, O.; Wingren, G. Health effects and exposure to polychlorinated biphenyls (PCBs) andmetals in a contaminated community. Environ. Int. 2012, 44, 53-58. [CrossRef]

9. Atuma, S.S.; Linder, C.E.; Wicklund-Glynn, A.; Andersson, O.; Larsson, L. Survey of consumption fish from Swedish waters for chlorinated pesticides and polychlorinated biphenyls. Chemosphere 1996, 33, 791-799. [CrossRef]

10. Danielovic, I.; Hecl, J.; Danilovic, M. Soil contamination by PCBs on a regional scale: The case of Strazske, Slovakia. Pol. J. Environ. Stud. 2014, 23, 1547-1554.

11. Passatore, L.; Rossetti, S.; Juwarkar, A.A.; Massacci, A. Phytoremediation and bioremediation of polychlorinated biphenyls (PCBs): State of knowledge and research perspectives. J. Hazard. Mater. 2014, 278, 189-202. [CrossRef] [PubMed]

12. Girvin, D.C.; Scott, A.J. Polychlorinated biphenyl sorption by soils: Measurement of soil-water partition coefficients at equilibrium. Chemosphere 1997, 35, 2007-2025. [CrossRef]

13. Pieper, D.H.; Seeger, M. Bacterial metabolism of polychlorinated biphenyls. J. Mol. Microbiol. Biotechnol. 2008, 15, 121-138. [CrossRef] [PubMed]

14. Furukawa, K.; Fujihara, H. Microbial degradation of polychlorinated biphenyls: Biochemical and molecular features. J. Biosci. Bioeng. 2008, 105, 433-449. [CrossRef] [PubMed]

15. Borja, J.; Taleon, D.M.; Auresena, J.; Gallardo, S. Polychlorinated biphenyls and their biodegradation. Process Biochem. 2005, 40, 1999-2013. [CrossRef]

16. Abraham, W.R.; Nogales, B.; Golyshin, P.N.; Pieper, D.H.; Timmis, K.N. Polychlorinated biphenyl-degrading microbial communities in soils and sediments. Curr. Opin. Microbiol. 2002, 5, 246-253. [CrossRef]

17. Vasilyeva, G.K.; Strijakova, E.R. Bioremediation of soils and sediments contaminated by polychlorinated biphenyls. Microbiology 2007, 76, 639-653. [CrossRef]

18. Dmochewitz, S.; Ballschmiter, K. Microbial transformation of technical mixtures of polychlorynated biphenyls (PCB) by the fungus Aspergillus niger. Chemosphere 1988, 17, 111-161. [CrossRef]

19. Yadav, J.S.; Quensen, J.F.; Tiedje, J.M.; Reddy, C.A. Degradation of polychlorinated biphenyl mixtures (Aroclors 642,654 , and 660) by the white rot fungus Phanerochaete chrysosporium as evidenced by congener-specific analysis. Appl. Environ. Microbiol. 1995, 61, 2560-2565. [PubMed]

20. Beaudette, L.A.; Davies, S.; Fedorak, P.M.; Ward, O.P.; Pickard, M.A. Comparison of gas chromatography and mineralization experiments for measuring loss of selected polychlorinated biphenyl congeners in cultures of white rot fungi. Appl. Environ. Microbiol. 1998, 64, 2020-2025.

21. Siracusa, G.; Becarelli, S.; Lorenzi, R.; Gentini, A.; Di Gregorio, S. PCB in the environment: bio-based processes for soil decontamination and management of waste from the industrial production of Pleurotus ostreatus. New Biotechnol. 2017, 39, 232-239. [CrossRef] [PubMed]

22. Ruiz-Aguilar, G.M.L.; Fernández-Sánchez, J.M.; Rodríguez-Vázquez, R.; Poggi-Varaldo, H. Degradation by white-rot fungi of high concentrations of PCB extracted from a contaminated soil. Adv. Environ. Res. 2002, 6, 559-568. [CrossRef]

23. Tigini, V.; Prigione, V.; Di Toro, S.; Fava, F.; Varese, G.C. Isolation and characterization of polychlorinated biphenyl (PCB) degrading fungi from a historically contaminated soil. Microbiol. Cell Factories 2009, 8, 5-13. [CrossRef]

24. Harms, H.; Schlosser, D.; Wick, L.Y. Untapped potential: Exploiting fungi in bioremediation of hazardous chemicals. Nat. Rev. Microbiol. 2011, 9, 177-192. [CrossRef] [PubMed]

25. Sage, L.; Périgon, S.; Faure, M.; Gaignaire, C.; Abdelghafour, M.; Mehu, J.; Geremia, R.A.; Mouhamadou, B. Autochthonous ascomycetes in depollution of polychlorinated biphenyls contaminated soil and sediment. Chemosphere 2014, 110, 62-69. [CrossRef] [PubMed]

26. Zeddel, A.; Majcherczyk, A.; Hüttermann, A. Degradation of polychlorinated biphenyls by white-rot fungi Pleurotus ostreatus and Trametes versicolor in a solid-state system. Toxicol. Environ. Chem. 1993, 40, 255-266. [CrossRef] 
27. Kubatova, A.; Matucha, M.; Erbanová, P.; Novotný, C.; Vlasáková, V.; Sasek, V. Investigation into PCB biodegradation using uniformly 14C-labelled dichlorobiphenyl. Isot. Environ. Health Stud. 1998, 34, 325-334. [CrossRef]

28. Kubatova, A.; Erbanová, P.; Eichlerová, I.; Homolka, L.; Nerud, F.; Sasek, V. PCB congener selective biodegradation by the white rot fungi Pleurotus ostreatus in contaminated soil. Chemosphere 2001, 43, 207-215. [CrossRef]

29. Federici, E.; Giubilei, M.; Santi, G.; Zanaroli, G.; Negroni, A.; Fava, F.; Petruccioli, M.; D'Annibale, A. Bioaugmentation of a historically contaminated soil by polychlorinated biphenyls with Lentinus tigrinus. Microb. Cell Factories 2012, 23, 11-35. [CrossRef]

30. April, T.M.; Foght, J.M.; Currah, R.S. Hydrocarbon-degrading filamentous fungi isolated from flare pit soils in northern and western Canada. Can. J. Microbiol. 2000, 46, 38-49. [CrossRef]

31. Bezalel, L.; Hadar, Y.; Fu, P.P.; Freeman, J.P.; Cerniglia, C.E. Initial oxidation products in the metabolism of pyrene, anthracene, fluorene, and dibenzothiophene by the white rot fungus Pleurotus ostreatus. Appl. Environ. Microbiol. 1996, 62, 2554-2559. [PubMed]

32. Novotný, Č.; Erbanová, P.; Šašek, V.; Kubátová, A.; Cajthaml, T.; Lang, E.; Krahl, J.; Zadražil, F. Extracellular oxidative enzyme production and PAH removal in soil by exploratory mycelium of white rot fungi. Biodegradation 1999, 10, 159-168. [CrossRef] [PubMed]

33. Aggelis, G.; Iconomou, D.; Christou, M.; Bokas, D.; Kotzailias, S.; Christou, G.; Tsagou, V.; Papanikolaou, S. Phenolic removal in a model olive oil mill wastewater using Pleurotus ostreatus in bioreactor cultures and biological evaluation of the process. Water Res. 2003, 16, 3897-3904. [CrossRef]

34. Rodríguez-Pérez, S.; García Oduardo, N.; Bermúdez Savón, R.C.; Fernández Boizán, M.; Augur, C. Decolourisation of mushroom farm wastewater by Pleurotus ostreatus. Biodegradation 2008, 19, 519-526. [CrossRef] [PubMed]

35. Zhao, L.H.; Zhou, J.T.; Lv, H.; Zheng, C.L.; Yang, Y.S.; Sun, H.J.; Zhang, X.H. Decolorization of cotton pulp black liquor by Pleurotus ostreatus in a bubble-column reactor. Bull. Environ. Contam. Toxicol. 2008, 80, 44-48. [CrossRef] [PubMed]

36. Gayosso-Canales, M.; Rodríguez-Vázquez, R.; Esparza-García, F.J.; Bermúdez-Cruz, R.M. PCBs stimulate laccase production and activity in Pleurotus ostreatus thus promoting their removal. Folia Microbiol. 2012, 57, 149-158. [CrossRef] [PubMed]

37. Thomas, D.R.; Carsweli, K.S.; Ceorgiou, C. Mineralization of biphenyl and PCBs by the white-rot fungus Pftanerochaete chrysosporium. Biokchnol. Bioeng. 1992, 40, 1395-1402. [CrossRef]

38. Pieper, D.H.; Winkler, R.; Sanderman, H., Jr. Formation of a toxic dimerization product of 3,4-dichloroaniline by lignin peroxidase from Phanerochaete chrysospurium. Angew. Chem. Inf. Ed. Engl. 1992, 31, 68-70. [CrossRef]

39. Yadav, I.S.; Quensen, J.F., III; Tiedje, J.M.; Reddy, C.A. Degradation of polychlorinated biphenyl (PCB) mixtures Aroclor 1242, 1254, 1260 by the white-rot fungus Phanerochaete chrysosporium as evidenced by congener specific analysis. Appl. Environ. Microbiol. 1995, 61, 2560-2565.

40. Stella, T.; Covinoa, S.; Burianová, E.; Filipová, A.; Křesinová, Z.; Vořǐšková, J.; Větrovský, T.; Baldrian, P.; Cajthamla, T. Chemical and microbiological characterization of an aged PCB-contaminated soil. Sci. Total Environ. 2015, 533, 177-186. [CrossRef]

41. Kirk, T.K.; Farrell, R.L. Enzymatic 'combustion': The microbial degradation of lignin. Annu. Rev. Microbiol. 1987, 41, 465-505. [CrossRef] [PubMed]

42. Pointek, K.; Glumoff, T.; Winterhalter, K. Low $\mathrm{pH}$ crystal structure of glycosylated lignin peroxidase from Phanerochaete chrysosporium at 2.5A resolution. FEBS Lett. 1993, 315, 119-124. [CrossRef]

43. Buswell, J.A.; Odier, E. Lignin biodegradation. CRC Crit. Rev. Biotechnol. 1987, 6, 1-60. [CrossRef]

44. Boominathan, K.; Reddy, C.A. Fungal Degradation of Lignin: Biotechnological Applications. In Handbook of Applied Mycology; Arora, D.K., Elander, R.P., Mukerji, K.G., Eds.; Marcel Dekker Inc.: New York, NY, USA, 1992; Volume 4, pp. 763-782.

45. Bumpus, J.A.; Tien, M.; Wright, D.; Aust, S.D. Oxidation of persistent environmental pollutants by a white rot fungus. Science 1985, 228, 1434-1436. [CrossRef]

46. Eaton, D.C. Mineralization of polychlorinated biphenyls by Phanerochaete chrysosporium: A ligninolytic fungus. Enzym. Microb. Technol. 1985, 7, 194-196. [CrossRef] 
47. Aust, S.D. Degradation of environmental pollutants by Phanerochaete chrysosporium. Microb. Ecol. 1990, 20, 197-209. [CrossRef]

48. Hammel, K.E. Oxidation of aromatic pollutants by lignin-degrading fungi and their extracellular peroxidases. In Metal Ions in Biological Systems; Siegel, H., Siegel, A., Eds.; Marcel Dekker Inc.: New York, NY, USA, 1992; Volume 28, pp. 41-60.

49. Lamar, R.T. The role of fungal lignin-degrading enzymes in xenobiotic degradation. Curr. Biol. 1992, 3, 261-266. [CrossRef]

50. Bumpus, J.A. White-rot fungi and their potential use in soil bioremediation processes. In Soil Biochemistry; Bollag, J.M., Statzky, C., Eds.; Marcel Dekker Inc.: New York, NY, USA, 1993; pp. 65-100.

51. Covino, S.; Stella, T.; Cajthaml, T. Mycoremediation of organic pollutants: Principles, opportunities, and pitfalls. In Fungal Applications in Sustainable Environmental Biotechnology; Purchase, D., Ed.; Springer: Basel, Switzerland, 2016; pp. 185-231.

52. Kamei, I.; Kogura, R.; Kondo, R. Metabolism of 4,4-dichlorobiphenyl bywhite-rot fungi Phanerochaete chrysosporium and Phanerochaete sp. MZ142. Appl. Microbiol. Biotechnol. 2006, 72, 566-575. [CrossRef]

53. Cloete, T.E.; Celliers, L. Removal of Aroclor 1254 by the white rot fungus Coriolus versicolor in the presence of different concentration of Mn(IV) oxide. Int. Biodeterior. Biodegrad. 1999, 44, 243-253. [CrossRef]

54. Kamei, I.; Sonoki, S.; Haraguchi, K.; Kondo, R. Fungal bioconversion of toxicpolychlorinated biphenyls by white-rot fungus, Phlebia brevispora. Appl. Microbiol. Biotechnol. 2006, 73, 932-940. [CrossRef]

55. Čvančarová, M.; Křesinová, Z.; Filipová, A.; Covino, S.; Cajthaml, T. Biodegradation of PCBs by ligninolytic fungi and characterization of the degradation products. Chemosphere 2012, 88, 1317-1323. [CrossRef] [PubMed]

56. Moeder, M.; Cajthaml, T.; Koeller, G.; Erbanová, P.; Šašek, V. Structure selectivity in degradation and translocation of polychlorinated biphenyls (Delor 103) with a Pleurotus ostreatus (oyster mushroom) culture. Chemosphere 2005, 61, 1370-1378. [CrossRef] [PubMed]

57. Borazjani, H.; Wiltcher, D.; Diehl, S. Bioremediation of polychlorinated biphenyland petroleum contaminated soil. In Proceedings of Environmental Science and Technology; Lyon, W.G., Hong, J., Reddy, R.K., Eds.; American Science Press: New Orleans, LA, USA, 2005; pp. 502-507.

58. Phan, C.; Sabaratnam, V. Potential uses of spent mushroom substrate and its associated lignocellulosic enzyme. Appl. Microbiol. Biotechnol. 2012, 96, 863-873. [CrossRef] [PubMed]

59. Chiu, S.W.; Law, S.C.; Ching, M.L.; Cheung, K.W.; Chen, M.J. Themes for mushroom exploitation in the 21st century: Sustainability, waste management and conservation. J. Gen. Appl. Microbiol. 2000, 46, 269-282. [CrossRef] [PubMed]

60. Di Gregorio, S.; Becarelli, S.; Siracusa, G.; Riffini Castiglione, M.; Petroni, G.; Masini, G.; Gentini, A.; Lima e Silva, M.; Lorenzi, R. Pleurotus ostreatus spent mushroom substrate for the degradation of polycyclic aromatic hydrocarbons: The case study of a pilot dynamic biopile for the decontamination of a historically contaminated soil. J. Chem. Technol. Biotechnol. 2016, 91, 1654-1664. [CrossRef]

61. Garcia-Delgado, C.; D’Annibale, A.; Pesciaroli, L.; Yunta, F.; Crognale, S.; Petruccioli, M.; Eymar, E. Implications of polluted soil biostimulation and bioaugmentation with spent mushroom substrate (Agaricus bisporus) on the microbial community and polycyclic aromatic hydrocarbons biodegradation. Sci. Total Environ. 2015, 508, 20-28. [CrossRef]

62. Garcia-Delgado, C.; Yunta, F.; Eymar, E. Bioremediation of multi-polluted soil by spent mushroom (Agaricus bisporus) substrate: Polycyclic aromatic hydrocarbons degradation and $\mathrm{Pb}$ availability. J. Hazard. Mater. 2015, 300, 281-288. [CrossRef]

63. Lau, K.L.; Tsang, Y.Y.; Chiu, S.W. Use of spent mushroom compost to bioremediate PAH contaminated samples. Chemosphere 2003, 52, 1539-1544. [CrossRef]

64. Gasecka, M.; Drzewiecka, K.; Siwulski, M.; Sobieralski, K. Evaluation of polychlorinated biphenyl degradation through refuse from Pleurotus ostreatus, Lentinula edodes and Agaricus bisporus production. Folia Hort. 2015, 27, 135-144. [CrossRef]

65. Jiang, G.X.; Niu, J.F.; Zhang, S.P.; Zhang, Z.Y.; Xie, B. Prediction of biodegradation rate constants of hydroxylated polychlorinated biphenyls by fungal laccases from Trametes versicolor and Pleurotus ostreatus. Bull. Environ. Contam. Toxicol. 2008, 81,1-6. [CrossRef]

66. Fujihiro, S.; Higuchi, R.; Hisamatsu, S.; Sonoki, S. Metabolism of hydroxylated PCB congeners by cloned laccase isoforms. Appl. Microbiol. Biotechnol. 2009, 82, 853-860. [CrossRef] [PubMed] 
67. Hietrich, D.; Hickey, W.J.; Lamar, R. Degradation of 4,4'-dichlorobiphenyl,3,3' $\mathbf{3}^{\prime}$ 4, $4^{\prime}$-tetrachlorobiphenyl, and $2,2^{\prime}, 4,4^{\prime}, 5,5^{\prime}$-hexachlorobiphenyl by the white rot fungus Phanerochaete chrysosporium. Appl. Environ. Microbiol. 1995, 61, 3904-3909.

68. Kourkoutas, Y.; Bekatorou, A.; Banat, I.M.; Marchant, R.; Koutinas, A.A. Immobilization technologies and support materials suitable in alcohol beverages production: A review. Food Microbiol. 2004, 21, 377-397. [CrossRef]

69. Guzik, U.; Hupert-Kocurek, K.; Krysiak, M.; Wojcieszyńska, D. Degradation potential of protocatechuate 3,4-dioxygenase from crude extract of Stenotrophomonas maltophilia strain KB2 immobilized in calcium alginate hydrogels and on glyoxyl agarose. Biomed. Res. Int. 2014, 2014, 1-8. [CrossRef] [PubMed]

70. Guzik, U.; Hupert-Kocurek, K.; Marchlewicz, A.; Wojcieszyńska, D. Enhancement of biodegradation potential of catechol 1, 2-dioxygenase through its immobilization in calcium alginate gel. Electron. J. Biotechnol. 2014, 17, 83-88. [CrossRef]

71. Guzik, U.; Hupert-Kocurek, K.; Wojcieszyńska, D. Immobilization as a strategy for improving enzyme properties-Application to oxidoreductases. Molecules 2014, 19, 8995-9018. [CrossRef] [PubMed]

72. Wojcieszyńska, D.; Hupert-Kocurek, K.; Jankowska, A.; Guzik, U. Properties of catechol 2,3-dioxygenase from crude extract of Stenotrophomonas maltophilia strain KB2 immobilized in calcium alginate hydrogels. Biochem. Eng. J. 2012, 66, 1-7. [CrossRef]

73. Dzionek, A.; Wojcieszyńska, D.; Guzik, U. Natural carriers in bioremediation: A review. Electron. J. Biotechnol. 2016, 23, 28-36. [CrossRef]

74. SæBø, A.; FErrini, F. The use of compost in urban green areas-A review for practical application. Urban For. Urban Green. 2006, 4, 159-169. [CrossRef]

(C) 2019 by the authors. Licensee MDPI, Basel, Switzerland. This article is an open access article distributed under the terms and conditions of the Creative Commons Attribution (CC BY) license (http://creativecommons.org/licenses/by/4.0/). 